\title{
Child Psychotherapy in a cultural-historical perspective: The movement of subjectivity in Art Therapy
}

\author{
Psicoterapia infantil na perspectiva cultural histórica: \\ o movimento da subjetividade em Arteterapia
}

Lara Nassar SCALISE1 ${ }^{1}$ (D) 0000-0003-1893-7929

Alexandra Ayach ANACHE1 (iD) 0000-0002-7937-4448

Maristela ROSSATO² (D) 0000-0001-6457-9005

\begin{abstract}
This paper presents an approach on psychotherapy for children using the theoretical foundations of subjectivity under a cultural and historical perspective. The purpose of this study is to understand the movement of subjective formations and processes in the psychotherapy context, through actions and relations developed in an Art Therapy atelier. This is the theoretical and methodological discussion of records elaborated by the therapist when caring for a 4-year-old girl. The principles of qualitative Epistemology proposed by González Rey inspired the analysis and construction of information along the study, which discusses the emphasis of the singularity, the dialogical relationship and constructive-interpretative character that recognizes interpretive psychotherapy, and the artistic practice as a driver of new processes of an individual subjectivities. It was found that the new subjective senses, which were produced from the induced tensions, allowed the recognition of the artistic practice as a driver of new processes of subjectivation, and provided conditions for the production of other, new subjective settings.
\end{abstract}

Keywords: Art therapy; Psychotherapy; Subjectivity.

\footnotetext{
1 Universidade Federal de Mato Grosso do Sul, Faculdade de Ciências Humanas, Programa de Pós-Graduação em Psicologia. Av. Costa e Silva, s/n., Bairro Universitário, 79070-900, Campo Grande, MS, Brasil. Correspondência para/Correspondence to: L.N. SCALISE. E-mail:<larascalise@hotmail.com>.

2 Universidade de Brasília, Instituto de Psicologia, Programa de Pós-Graduação em Processos de Desenvolvimento Humano. Brasília, DF, Brasil

Support: Programa Nacional de Pós-Doutorado da Coordenação de Aperfeiçoamento de Pessoal de Nivel Superior.

Article based on the postdoctoral thesis of L.N. SCALISE \& A.A. ANACHE, entitled "Reinvenção da Psicoterapia por meio da Arteterapia: aproximações com a perspectiva histórico-cultural”. Universidade Federal de Mato Grosso do Sul, 2016.
}

\section{Como citar este artigo/How to cite this article}

Scalise, L. N., Anache, A. A., \& Rossato, M. (2019). Child Psychotherapy in a cultural-historical perspective: The movement of subjectivity in Art Therapy. Estudos de Psicologia (Campinas), 36, el80033. http://dx.doi.org/10.1590/1982-0275201936e180033 


\section{Resumo}

Este trabalho apresenta a psicoterapia infantil na perspectiva cultural e histórica. Tem por objetivo compreender o movimento dos processos e formações subjetivas, em contexto psicoterápico, por meio de ações e relações desenvolvidas em um ateliê de arteterapia. Trata-se da discussão teórico-metodológica de registros elaborados pela autora/terapeuta em atendimentos a uma menina de quatro anos. A análise e construção das informações inspiraram-se nos princípios da Epistemologia qualitativa propostos por González Rey, que discute a ênfase do singular, a relação dialógica e o caráter construtivo-interpretativo, reconhecendo, na psicoterapia, o fazer artístico como condutor de novos processos de subjetivação do indivíduo. A presente pesquisa evidencia que os novos sentidos subjetivos, produzidos a partir dos tensionamentos provocados, proporcionaram condições para a produção de outras e novas configurações subjetivas.

Palavras-chave: Arteterapia; Psicoterapia; Subjetividade.

This article aims to understand the movement of processes and subjective formations, in a child psychotherapeutic context, through actions and relationships developed in an Art Therapy studio. Psychotherapy is a meeting of people in which there is no sovereignty between the therapist and the child, in view of being an educational space in which new learning for both is produced. Although the roles are distinct, it is necessary, for the bond to be established, the recognition of the affective presence of the other, thus favoring relations of exchange in which places and knowledge are defined (Bezerra \& Rossato, 2018).

Psychotherapy is able to develop its own resources for people to exit a situation that causes them suffering, it is constituted in the process of producing new systems of subjectivation, thus, "in view of its current situation it is capable of producing new emotions and symbolic processes that facilitate the development of new subjective meanings" (González Rey, 2007, p.160).

The reasons that generate the demand for psychotherapeutic services can not be considered prematurely as pathological, requiring the professional to be an investigator in the search for explanations and possibilities for change, since psychotherapy is a process of production of new systems of subjectivation, which stress the whole system of subjective configurations, not being limited to the solutions centered on the figure of the therapist. This tension can be a trigger to the production of new subjective senses, promoters of subjective reconfigurations, that will form the basis to the confrontation of problems.

Subjective configurations, in their organicity, constitute the personality, and are the basis to the actions and relations of the subject, of his life story and his culture. Therefore, "personality is no more than a configuration of subjective configurations" (Mitjáns Martínez \& González Rey, 2017, p.56). Personality is understood as a relatively stable and systemic organization, a producing instance of subjective senses and meanings in the various moments of the person's action. The experiences appear subjectivated in different configurations through the emotions, reflections and significations that are produced in the course of life of the individual. Therefore, it is constituted when it becomes for itself that which was previously in itself, that is, that which was, as Vigotski (1991, p.64) affirmed: "The transformation of an interpersonal process in an intrapersonal process is the result of a long series of events occurring throughout their development"; in other words, the process of subjectivation of experience is both individual and social.

Psychotherapy consists of spaces/times in which social subjectivity and individual subjectivity are articulated. Therefore, the relations between these different levels are "processes that are configured in a reciprocal, permanent way in which one is part of the nature of the other" (Mitjáns Martínez \& González Rey, 2017, p.53). In this relational space/time, new emotions and symbolic processes are mobilized that, depending on their qualitative nature, can promote subjective development, breaking with a damaging

2 configuration present up to that moment. 
In this way, the therapeutic relationship drives the way the current situation is subjectively configured, through the tension it generates, involving the repositioning of the individual, the members of his family, and other people of his social coexistence. This movement is important for subjective development, positively impacting the health of those involved by promoting new subjective senses (González Rey, 2007).

The subjective senses are produced as a symbolic-emotional mobilization, in the actions and relations lived, that lead the individual to become the subject. In the process of psychotherapy, considering the nature of tensions generated by the resources available to them, this process can evolve towards the confrontation of the presented problems.

Psychotherapy, as a process of production of new subjective senses that entitle the individual to become a subject, has been signaled for several decades by authors such as Foucault (2008), Ratner (1995), Szasz (1976), Vigotski (2001), and more recently by Brazilian authors, such as Anache and Luz (2014), Batista and Tacca (2015), Cupolillo (2013), Mitjáns Martínez (2014), Mori (2014), Neubern (2014). These authors have constructed references in order to understand the dynamics of psychological phenomena in the cultural and historical context, breaking with the practices that medicalize the different manifestations of the person, which deviate from the established norm.

Subjectivity is "a complex system produced simultaneously at social and individual levels, independent of the fact that, at the same time of their production, we recognize its historical social genesis" (González Rey, 2003, p.202). In this direction, the author breaks with the dichotomy between the individual and the social, amplifying the understanding of the singularity of the subject. Individual subjectivity represents the processes and forms of organization that constitute the life story of each one of us. Social subjectivity permanently crosses individuality, stimulating the person to produce new subjective senses, which develop into the network of social relations.

Thus, it is emphasized the importance of the concepts of social situation of development and Perezhivanie, as presented by Vygotsky (The Psychology of Art), to understand the development of the psyche of the subject, as they allow us to analyze the way the child, according to his level of development, is affectively related to the influences of the environment (Mitjáns Martínez \& González Rey, 2017).

Perezhivanie is constituted as a psychological unit of human development, because the external influences that a human being experiences are faced from his psychological organization, which was defined by Vygotsky (1994) as a social development situation (Mitjáns Martínez \& González Rey, 2017). Therefore, these concepts are fundamental to understand the complexity of the organization of psychological processes, and specially because Perezhivanie indicates how the individual constructs the subjective senses of his experiences, from which they integrate the subjective configurations.

\section{Psychotherapy through art-therapeutic experiences}

In this perspective, psychotherapy considers that the human being is constituted through educational processes (informal and formal), which promote in the lived experiences the learning for the development of new senses of subjectivation that aim to modify the subjective configurations, promoting a new repositioning of the subject in relation to their present suffering. The experiences provided by Art Therapy, mobilizes emotions and feelings that can promote and expand self-knowledge. They are new experiences learned that enable the production of new meanings and significances about situations that integrate the subject's life story. Barros and Ferreira (2016), Coqueiro, Vieira, and Freitas (2010), Reis (2014), Saviani (2004), carried out studies on the importance of Art Therapy as a means of health promotion and found that this is a valuable resource to stimulate creativity, besides being a mechanism of psychic rebalancing. 
The context of psychotherapy has the objective of providing the individual with conditions so that he can develop himself as a subject, that is, that he takes an active position in confronting situations of conflict. The subject represents, therefore, the capacity of positioning in the current events and experiences in which he is inserted, opening a proper path of subjectivation (Mitjáns Martínez \& González Rey, 2017). In this process, the actions and relations built with the psychotherapist in the Art Therapy studio are fundamental in the structuring of artistic production, adding to it symbolic-emotional values. Artistic activities are inducers of the subjective expression of the subject, requiring that the therapist is attentive to the cultural elements of the social group in which this subject is inserted. In González Rey's (2005, p.65) conception, "the inductors that can be at the basis of any instrument are part of the infinite repertoire of symbolic operations of people in their cultural contexts", which can promote the expression of subjects in the context which it applies.

Interventions created through the activities that are carried out provide possibilities for building new learning to cope with life-threatening situations that may constitute a source of distress and anxiety. Therefore, the production of subjective meanings in the face of challenges that art is capable of promoting in psychotherapy can be mobilizers of new processes and subjective formations in the confrontation of problems experienced by the child and his relatives (Mitjáns Martínez \& González Rey, 2017).

The resources used in artistic production enable the child to relate reality to fantasy, the inner world to the external world, enabling him to express symbolic-emotional contents, with which we can then dialogue, tensioning, thus providing self-knowledge and, consequently, personal development.

In the same way, art is a social technique of feeling, an instrument of society through which the most intimate and personal aspects of our being are incorporated into the cycle of social life, it would be more correct to say that feeling does not become social, on the contrary, becomes personal, when each one of us experiences a work of art, it becomes personal without ceasing to continue social (Vigotski, 2001, p.315).

Art expresses ways of living, in actions and social relations, "as knowledge of life" (Vigotski, 2001, p.328), enabling the person to become a subject in the therapeutic relationship, through new productions of subjective senses.

\section{The rise of Art Therapy in clinical spaces}

Art Therapy is an expression mostly used in the last two centuries, however, art has always been used by the various peoples to communicate and express desires, anxieties, emotions, affections and feelings. If we make a survey of the use of art as an expression of human subjectivity, we will find various pieces of information about its use as a possibility of human understanding, object of scientific study, recognized as "one of the vital functions of society" (Vigostski, 2001, p.9). It is a practice that presents itself as a way to know the psyche of individuals and the phenomena of social life; the art, besides the various forms of artistic expression, becomes a specific work instrument in several fields of Psychology. Artistic language, by providing conditions for the individual to express their inner experiences, favors the expansion of consciousness about them (Ciornai, 1995). Andrade (2000) added that it facilitates the expression of the interiority of man, and thus favors communication with the therapist.

Vasques (2009), when carrying out a bibliographical survey on Art Therapy, reports that there are several ways of understanding it, considering both the theoretical approach and its functions. He presented the main modalities used in this field, being drawing, painting, collage, engraving, weaving, modeling,

4 sculpture, construction of projects, theater, games, creative writing. 
The creative function of art is a common point between psychological approaches, since it places the subject as the maker and producer of a work, guaranteeing conditions for reflection, hence its formative character. In the version of Reis (2014), creating is also forming or even giving shape to something new. This process allows the subject to organize internally, to produce new senses, to elaborate them through the integration of meanings and to communicate them, hence the transforming power of art as creative action.

\section{Method}

This research was inspired by the Qualitative Epistemology developed by González Rey (2002, 2005), which recognizes knowledge as a complex interpretation of reality, since this is a multi-domain field of events that interrelate and interchange. It is characterized by three basic principles: the constructive-interpretative character of the construction of knowledge; the legitimation of the singular contribution that a particular case can bring to knowledge; the dialogical and communicational relationship in the course of research.

Knowledge is recognized in the constructive-interpretative process as an open, non-linear field that provides reflections that generate fundamental hypotheses for the construction of information, as well as "[...] feeding on new meanings generated in research and professional practice, implies the enrichment of the essential categories of theory, as well as the genesis of new categories as a necessary expression of the development of this theoretical system" (González Rey \& Quevedo, 2017, p.28).

Theories are living systems that guide the steps of researchers, [...] who are stimulated by new meanings generated in research and professional practice, implies the enrichment of the essential categories of theory, as well as the genesis of new categories as a necessary expression of development of this theoretical system (González Rey, 2014, p.28). The construction of information takes into account the articulation with the theoretical framework, producing indicators that guide the researcher's actions in the analyzes elaborated in the different moments of research, which constitute the perception and understanding of all the complexity of the phenomenon studied. In this sense, the research is not limited to the definition of categories, but it is in them that the indicators that transcend the limits of the evidence are produced enabling new indicators.

The second principle rescues the importance of the unique contribution of each case to the problem being studied. The unique value of each production is emphasized to the theoretical model under construction, after all, the subject is always in his own path of subjectivation, through creative experiences that transcend the passive-reproductive process, that is, the normative social space (Mitjáns Martínez \& González Rey, 2017).

The third principle of Qualitative Epistemology is characterized by the emphasis on dialogic communication between the researcher and the research participants. This relationship implies in permanently promoting a reflexive tension of the other, through open conversational spaces, that promote a relational space between subjects (Mitjáns Martínez \& González Rey, 2017).

For the purposes of empirical analysis, the records of the Art Therapy professional, the first author of this work, were used and analyzed and organized with the purpose of presenting the information and the movement of the subjective processes and formations, in a psychotherapeutic context, through actions and relationships developed in an Art Therapy studio. We present, initially, the service locus, considered as a space under construction, called atelier. Next, we describe the analysis and information of the care process of a child, chosen as a participant in this study.

This psychotherapeutic intervention assumed the ethical commitment of the profession of psychologist, prescribed by the Psychology Ethics Code of the Conselho Federal de Psicologia (Brazilian Federal Psychology Council), as well as submitting the research to the Human Beings Ethics Committee, under the approval $n^{\circ} 1469008$ and CAAE $n^{\circ} 52956115600000021$, enrolled in the platform Plataforma Brasil. 


\section{From the clinic to the atelier: A space for building}

When a person seeks psychological help, they are looking for solutions to their problems or their conflicts. In the case of a child, this is usually the expectation of the parents or guardians. Traditionally, the psychologist assumes the role of promoter of changes in the patient's current situation.

We conceive the problems as part of the subject's life as a driving force to destabilize him and, from there, to construct other ways to face these problems. According to González Rey (2007, p.161), "The other paths" are possibilities to be constructed artisanally, deciphering each "act", each step, promoting the development of reflections and consequently of new subjective senses. it is not a process of discoveries or solutions centered on the figure in the therapist, it is a process of production of new systems of subjectivation.

We recognize an Art Therapy studio based on the French meaning for "studio", which is defined as a space for building, in which it is possible to experiment, manipulate and produce the most varied types of art; in this way, associated with psychotherapy, it constitutes a space where a person, in therapy, can express emotions and feelings through artistic activity, which appear in their symbolic productions.

The Art Therapy studio is the space where the scenario for the development of actions and relationships that aim at the production of subjective senses in the process of coping and overcoming conflicts will be built, thus promoting the emergence of the subject. The concept of a "social setting" is essential in the transformation of the idea from a clinic to an atelier, taking the centrality and omnipotence of the psychotherapist from the process of "cure" of problems, to the emphasis on the construction of possibilities of coping with the conflicts for the subject. For Rossato, Martins, and Mitjáns Martínez, (2014, p.14).

[...] building the social context of the research would be like constructing a theatrical scenery with lights, colors, furniture, textures, where it is possible to establish a communication relationship between actors and spectators: a space of communication and dialogue. [...] the construction of the social context of the research, so it is an invitation to the participants/spectators to come on stage and to be protagonists, to describe, narrate, expose their stories, their feelings, their joys and sorrows, their dreams and their disappointments. However, success depends on the participants perceiving themselves as subjects and wanting to be part of this spectacle.

The visual stimuli that are present in the studio are intended to inspire the possibilities of activities to be performed. For this, the studio is organized from the entrance, at the gate, where the floor is marked with stains of different colors of paints, the walls that lead the hallway to the doors of the clinics are all colored, in pieces, each in a different color.

There are two rooms reserved for clinical practice, one with two children's tables, two large sinks and shelves with plastic boxes containing materials for artistic activities, accessible to children. There is a green chalkboard, and many arts activities on display. The second room has three tables with colorful chairs, for treating teenagers and adults. A wall full of comic books, like a wall paper, a piece of the ceiling with colored plastic balls glued together, those used in a ball pool for children; a table, which is for the therapist, whose design and position allows the therapist not to be behind it, but in front of it; a shelf for games and two keyless lockers store other therapy material to which participants can have free and spontaneous access.

In each session, after defining what will be done, always in partnership with the child, with the psychologist's orientation, the focus is on the activity and the observation of the process of treatment. Many children face difficult choices and the stimuli are a form of intervention, since they require their own positions. The meetings are individual with a duration of 45 minutes.

Different materials are used, from stationery and arts items to alternative ones such as scrap and recyclable material, used according to each child's need for the activity to be built. These constitute an inductive instrument that provokes the expression of subjective contents, allowing the professional to construct information about the psychological dynamics of the child, through constructive-interpretative analysis. 
The proposal has art as a process of the production of emotions, through the construction of created activities, which allows the creator to recognize them and, thereby, establish a channel of communication with himself, promoting an invitation to reflect upon the motives that generate the situation in which he is placed.

The subjective senses that are being produced by the children in treatment in the studio constitute symbolic-emotional psychological units, being considered mobilizers of psychological resources, that alter and lead the subject to a new production of subjective configurations (Rossato et al., 2014).

In the execution of activities, what matters is not the fact itself, but as the subjective subject this experience, fundamental to allow free expression to occur through the built. It is the invitation to the creation and symbolic production of feelings and the possibility of producing new subjective meanings, as stated by González Rey (2005) and added by Rossato et al. (2014, p.39): "[...] the experience of a fact in itself that matters, but how the subject, imbricated in the lived experience, subjectivate that experience". For example, pain arising from a trauma exists for the subject at the time it occurs, but what matters after this fact is how the subject deals with this experienced situation.

\section{Analysis and discussion of information: Psychotherapy as a space for the production of new, other subjective meanings}

\section{The search for therapy and analysis of the reasons for the consultation}

The research participant is a 4 year old girl who was in therapy in 2012, whom we call Clara, a private school student, in prekindergarten. Among the characteristics presented by the mother are those of a child "shy, showing withdrawal behavior in relations with people" (Excerpt from the interview with the mother). In the meetings with Clara, we observed a child with good verbal fluency and vocabulary according to the grammatical norms of the Portuguese language, characteristics common to a 6 year old child.

In the initial meetings we tried to understand the reasons for the search for therapy. The option for the term "motives" rather than "initial complaint" aims to break with the biomedical diagnostic model to thus identify facts of the child's life story without focusing on a problem, and raising parents' expectations and possible contributions of psychological care.

Clara was brought by her mother, presenting difficulties to separate herself from the mother, especially in the school space, at the moment of school entry. The mother reported that she had already made several attempts and various strategies in the face of her daughter's difficulty. The meeting in the atelier was carried out through conversational dynamics, as described by González Rey (2011). Thus, we established dialogues to understand the child's life story in relation to the reasons that led to therapy. The difficulty presented guided our actions; during the meetings we identified indicators that led to the understanding of the problem, aware that other reasons would be recognized in the continuity of psychotherapy, considering that all the therapeutic conduction would be done in a total of 12 meetings.

\section{Therapeutic conduction and the movement of subjective processes and formations produced by} Clara

On the first encounter, Clara arrived hand in hand with her mother; I took her hand to present the studio, as I do with every child, but she did not let go of her mother's hand, holding it very tightly. I continued presenting the studio, in order to invite her to venture into new challenges, among which the participation and construction of artistic activities stands out. 
After two meetings, Clara accepted to stay without the presence of the mother in the studio, verbalizing, initially, with doubts, according to her report "I do not know if it is a good idea". But when she did so, I assured her that her mother would be around waiting for her, and that we would do a surprise activity for her, and that she must be absent. The girl accepted, and we followed our session, motivated by this proposal.

We started suggesting that Clara's mother gradually moved away from the atelier, so that it would be possible to strain the already consolidated bonds of the relationship between them. This moment was fundamental for the reconstitution of the subjective processes and formations between the two, and consequently a necessary moment for Clara's psychological development, given her attitudes in subsequent encounters, when she dispensed with the presence of her mother. Considering that the difficulty that the girl had to enter the school alone was the main reason of the search for psychological care, due to the anguish that Clara showed when separating from her mother, we were looking for information that promoted the understanding of the processes and subjective formations involved in the separation of her parent, because the anguish she felt with the absence of the mother also extended to other environments, even at home.

Some information from the parents caught our attention, among them the mother's report that justified the precocity of Clara for being an only child and to having lived more with adults. This precocity to which the mother referred was expressed in language, organization and commitment to school activities.

In Art Therapy activities that used scissors and brushes, we raised another indicator of the conflict for Clara: facing her manual abilities, she was very demanding to herself in order to perform these activities and to use these materials correctly. We know that children between 3 and 4 years old have more difficulty in performing the use of materials that require fine motor coordination skills; the drawings have scribbled lines, but already using circular lines, already bringing the images closer to reality with the demonstration of symbolic contents (Greig, 2004), which refer mainly to family and school experiences.

We return to the concept of Perezhivanie as a basis for understanding the different subjective configurations that children develop in the course of their experience. In this sense, Mitjáns Martínez and González Rey (2017) deepened these concepts because they are fundamental to the understanding of subjectivity, since the subjective senses are correlated to the different moments of the subject's life and in their more diverse contexts resulting from the tension between the subjective constitution and the current production. Therefore, "it is necessary to know and explain how these contents participate in the regulation of behavior" (Mitjáns Martínez \& González Rey, 2017, p.80).

It is noted that her early intellectual development to understand the activities that were requested, such as painting, collage, among others, Clara expressed her high level of requirement to perform them the way she imagined to be correct, which inspired us to the construction of challenging situations so that she could be motivated when facing them. For the mobilization of new subjective senses it was necessary to promote art therapeutic activities using play dough, making a picture with her name, a box decorated with wool yarn and other materials, decoupage with napkins, etc. The dialogue developed during the activities was always of tension and encouragement to carry out activities with autonomy and independence. In this process, we perceived a desire for autonomy in Clara's actions, demonstrated in her ability to manage precocious attitudes (for her age), but the independence required to perform activities without assistance, especially everyday activities, such as entering the school alone, was creating a conflict with her and her parents.

These experiences, provoked by the new things learned in the making of artistic activities, opened possibilities for us to make the interventions that stimulated Clara to think about her advances in relation to her independence to develop the proposed activities. One activity that paved the way for our proposal was when Clara chose a napkin with some animals to glue on a canvas. On that occasion the dialogue was 8 conducive to challenge her in the face of conflict, as the following fragment illustrates. 
Therapist: Oh, I think I have understood why you do not go to school alone.

Clara: Have you?

Therapist: You do not know the way of your classroom. You are afraid of getting lost inside school. Clara: I know the way to my classroom.

Therapist: But then, why do you need your mother to take you to your room every day? Tomorrow I want you to show me if you really do, by going to your classroom by yourself.

This tension moved Clara, challenging her to meet her difficulty to separate from her mother, when she accepted our proposal and did so the next day, entering the school alone. Since then, we have witnessed each activity the development of confidence in the execution of the exercises provided in the 12 meetings we had. The changes in Clara's attitudes, which have been described, indicated that new psychic formations were present. For Vygotsky (1996), neoformations are understood as the type of personality structure, fundamental psychic and social changes for consciousness, in their relation to the environment, and in the internal and external aspects of their lives, in a given period in the development of the child.

The propitious conditions of the situation in which Clara was inserted, among which the availability of her mother, empowering her emotionally to seek other experiences without her physical presence, was fundamental to mobilize the resources that both possessed to produce new subjective senses, aiming at overcoming a dependency-based relationship, which placed them both in comfort zones, but which at one point began to generate problems.

Thus, all planned activities were those in which she showed greater interest, such as painting, building objects with play dough, and drawing. To the extent that Clara was producing something, we were discussing the most varied subjects, including the demands she placed upon herself, especially when it came to drawing or painting with the utmost perfection. Gradually, she realized that mistakes were inevitable and were part of what she had set as success criteria.

The movement of overcoming these self-demands could be observed when Clara enthusiastically invited her father to get to know the studio - the space she calls "the place where one fixes-errors!". Surprised by this expression, we asked her to explain her conclusion: Clara told us, "I learned from you!". We certainly learned together!

Thus, psychotherapy, traditionally known as a psych treatment space, often in a medicalized version, can be understood as a place of learning, where people are promoted through encounters with different life experiences, mobilizing the forces of available resources to move other psychological functions, still at an embryonic stage. Therefore, it has the function of expanding the child's experience, providing the foundation for his creations. Vigotski $(2014$, p.13) stated that "[...] the more elements of reality the child has available to his experience, more important and productive, in different circumstances will be his imaginative activity".

Imagination has the function of enlarging the experience of the individual, through the relationships he establishes with the others, breaking the boundaries of what has been spoken and what has been lived, and thereby allowing creation. It means, therefore, to say that the products of the imagination are constructed from the transformed elements of reality, and it is necessary to have resources derived from accumulated experience. There is a close dependence between imagination and experience, one leaning on the other, being a process charged with emotions and affections, which are revealed in the different images (Vigotski, 2014). Nevertheless, in this perspective, imagination is fundamental to the intellectual activity of man.

Therefore, when Clara allowed herself to make and fix mistakes, she synthesized several elements that came out of her experience in our sessions. We may say that the combination of the elements of the newly imagined production (creation) contains other elements already transformed, which have been tempered 
by feelings and affections. Vigotski (2014), in using the tale narrated by Pugatchov to exemplify the relation between imagination and reality, emphasized that, at first, the tale seems fanciful or even detached from external reality but that it brought forth the internal reality - these are internal truths that are concrete, real and constitute material for analysis of the mental life of the individual. In this sense there is no dichotomy between internal and external.

We learned from Vigotski $(2014$, p.24) that in a work of art it is possible: "[...] to find together often distant traits without any external bonds, though not unknown to one another, like the thought about a toothache and the thought about getting married, but united according to an internal logic".

We were interested in analyzing Clara's different forms of expression in her activities, because they were important to know more about her and, above all, to identify her level of development, that is, what she had already acquired and the that she could learn from us, what Vygotsky calls the Zone of Eminent Development. It is the distance between the child's current development, which is defined with the help of questions that the child solves alone, and the child's level of development that is defined with the help of problems that he solves under the guidance of adults and with smarter companions (Prestes, 2010, p.173).

In this perspective, in the course of the sessions in the atelier, we position ourselves as both Clara and her family's advisors in the learning process, and we understand that the crisis situation that motivated them to look for help was necessary for the development of everyone involved, especially the child, after all, one learns to live by experiencing other ways of being, in other spaces and in the company of other people.

\section{Final Considerations}

Considering the above, we recognize child psychotherapy as a space/time of movement of subjective processes and formations. The new subjective senses that were produced from the tensions provoked by the therapist, allowing Clara to make and fix mistakes, made it possible to reconfigure the way in which her own self-demand was constituted subjectively.

The Art Therapy atelier has shown to favor new possibilities, new ways to implement actions within the psychotherapeutic context, taking the psychological phenomena out of the enclosure of pathology clinics, opening proposals for practices that qualify the different expressions of the subject in the face of difficulties that appear in concrete conditions of life, without enclosing them in pre-established classifications, breaking with the supremacy of the biomedical model.

However, it is necessary to move forward in the construction of proposals for guidelines and therapeutic relationships that require a deepening in the perspective announced and that constitute as conducive to new studies for the practice of psychology in this field. It is necessary to advance in the method proposed by the Subjectivity Theory to investigate the genesis of the formation of ongoing psychological processes.

\section{Contributors}

L.N. SCALISE was responsible for the conception and design, information production, analysis and interpretation of data, article elaboration. A.A. ANACHE contributed in the conception and design, analysis and interpretation of data, orientation in the article elaboration. M. ROSSATO contributed with the theoretical and methodological foundations of this study, revision and approval of the final version of this article. 


\section{References}

Anache, A. A., \& Luz, H. (2014). O lugar da subjetividade no Processo de Avaliação Diagnóstica do Indivíduo com Deficiência Intelectual: desafios metodológicos e epistemológicos. In A. Martínez Mitjáns, M. Neubern, \& V. D. Mori (Orgs.), Subjetividade contemporânea: discussões epistemológicas e metodológicas. Campinas: Alínea.

Andrade, L. Q. (2000). Terapias expressivas. São Paulo: Vetor.

Barros, M., \& Ferreira, L. (2016). A arte como estratégia de intervenção psicoterapêutica. Psicologia e Saúde em Debate, 2(Supl.1), 1-4. http://dx.doi.org/10.22289/2446-922X.V2S1A1

Batista, A. S., \& Tacca, M. C. V. R. (2015). Histórias de subjetividade e aprendizagem: reconhecendo competências onde imperava o limite. Curitiba: CRV.

Bezerra, M. S., \& Rossato, M. (2018). Relational dynamics in overcoming school learning difficulties. In F. González Rey, A. Mitjáns Martínez, \& D. M. Goulart (Eds.), Theory of subjectivity-new perspectives within social and educational research.

Ciornai, S. (1995). Arte-terapia: o resgate da criatividade na vida. In M. M. M. J. Carvalho (Org.), A arte cura? recursos artísticos em psicoterapia (pp.59-63). Campinas: Editorial Psy II.

Coqueiro, N. F., Vieira, F. R. R., \& Freitas, M. M. C. (2010). Arteterapia como dispositivo terapêutico em saúde mental. Acta Paulista de Enfermagem, 23(6), 859-862. Recuperado em novembro 11, 2017, de http://www.redalyc.org/ articulo.oa?id=307023868022

Cupolillo, M. V. (2013). Os entrelaces dos cachinhos de Gabriela: reflexões sobre psicoterapia, educação e cidadania. Rio de Janeiro: Multifoco.

Foucault, M. (2008). O nascimento da clínica. Rio de Janeiro: Forense.

González Rey, F. (2002). Pesquisa qualitativa em Psicologia: caminhos e desafios. São Paulo: Pioneira Thomson Learning.

González Rey, F. (2003). Sujeito e subjetividade: uma aproximação histórico-cultural. São Paulo: Pioneira Thomson Learning.

González Rey, F. (2005). Pesquisa qualitativa e subjetividade: os processos de construção da informação. São Paulo: Pioneira Thomson Learning.

González Rey, F. (2007). Psicoterapia, subjetividade e pós-modernidade: uma aproximação histórico-cultural. São Paulo: Pioneira Thomson Learning.

González Rey, F. (2011). Subjetividade e saúde: superando a clínica da patologia. São Paulo: Cortez.

González Rey, F. (2014). Ideias e modelos teóricos na pesquisa construtiva-interpretativa. In A. Mitjáns Martínez, M. Neubern, \& V. D. Mori (Orgs.), Subjetividade contemporânea: discussões epistemológicas e metodológicas. Campinas: Alínea.

González Rey, F., \& Quevedo, J. E. M. (2017). Subjetividad, cultura e investigación cualitativa: Ios antecendentes desde la personalidade y el método clínico. Bogotá: Editorial Aula de Humanidades.

Greig, P. A. (2004). Criança e seu desenho: o nascimento da arte e da escrita. Porto Alegre: Artmed.

Mitjáns Martínez, A. (2014). Um dos desafios da epistemologia qualitativa: a criatividade do pesquisador. In A. Mitjáns Martínez, M. Neubern, \& V. D. Mori (Orgs.), Subjetividade contemporânea: discussões epistemológicas e metodológicas. Campinas: Alínea.

Mitjáns Martínez, A., \& González Rey, F. (2017). Subjetividade: teoria, epistemologia e método. Campinas: Alínea.

Mori, V. D. (2014). A epistemologia qualitativa na pesquisa em saúde: suas implicações e desafios. In A. Mitjáns Martínez, M. Neubern, \& V. D. Mori (Orgs.), Subjetividade contemporânea: discussões epistemológicas e metodológicas. Campinas: Alínea.

Neubern, M. S. (2014). Subjetividade e espiritualidade em sociedade de universos múltiplos: problemas de pesquisa clínica e qualitativa. In A. Mitjáns Martínez, M. Neubern, \& V. D. Mori (Orgs.), Subjetividade contemporânea: discussões epistemológicas e metodológicas. Campinas: Alínea.

Prestes, Z. R. (2010). Quando não é a mesma coisa: análise de traduções de Lev Semionovitch Vigotski no Brasil: repercussões no campo educacional (Tese de doutorado não-publicada). Universidade de Brasília.

Ratner, C. (1995). A psicologia sócio-histórica de Vygotsky. aplicações contemporâneas. Porto Alegre: Artes Médicas.

Reis, A. C. (2014). Arteterapia: a arte como instrumento no trabalho do psicólogo. Psicologia: Ciência e Profissão, 34(1), 142-157. Recuperado em abril 12, 2017, de http://www.scielo.br/pdf/pcp/v34n1/v34n1a11 
Rossato, M., Martins, L. R. R., \& Mitjáns Martínez, A. (2014). A construção do cenário social da pesquisa no contexto da epistemologia qualitativa. In A. Mitjáns Martínez, M. Neubern, \& V. D. Mori (Orgs.), Subjetividade contemporânea: discussões epistemológicas e metodológicas. Campinas: Alínea.

Saviani, I. (2004). Ateliê terapêutico - Encontrar te: vivier arte, criar e recriar a vida. In S. Ciornai (Org.), Percursos em arteterapia: arteterapia gestáltica, arte em psicoterapia, supervisão em arteterapia (pp.49-81). São Paulo: Summus Editorial.

Szasz, T. S. (1976). A fabricação da loucura. São Paulo: Zahar.

Vasques, M. C. P. C. F. (2009). A arteterapia como instrumento de promoção humana na saúde mental (Dissertação de mestrado não-publicada). Universidade Estadual Paulista, Faculdade de Medicina de Botucatu. Recuperado em setembro 18, 2017, de https://repositorio.unesp.br/bitstream/handle/11449/98472/vasques_mcpcf_me_botfm. pdf? sequence $=1$ \&isAllowed=y $\% 20=$

Vigotski, L. S. (1991). A formação social da mente: o desenvolvimento dos processos psicológicos superiores. (4a ed.). São Paulo: Martins Fontes.

Vigotski, L. S. (2001). Psicologia da arte. São Paulo: Martins Fontes.

Vigotski, L. S. (2014). Imaginação e criatividade na infância. São Paulo: Martins Fontes.

Vygotsky, L. S. (1994). The problem of environment. In R. V. D. Veer \& J. Valsiner. The Vygotsky reader. Cambridge: Blackwell. Vygotsky, L. S. (1996). Obras escogidas (Vol. 4). Madrid: Visor.

Received: March 22, 2018

Final version: July 26, 2018

Approved: September 13, 2018 